FF 459
G9 $\mathrm{W2}$
opy 1

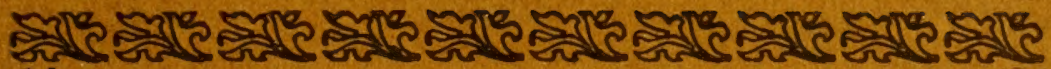

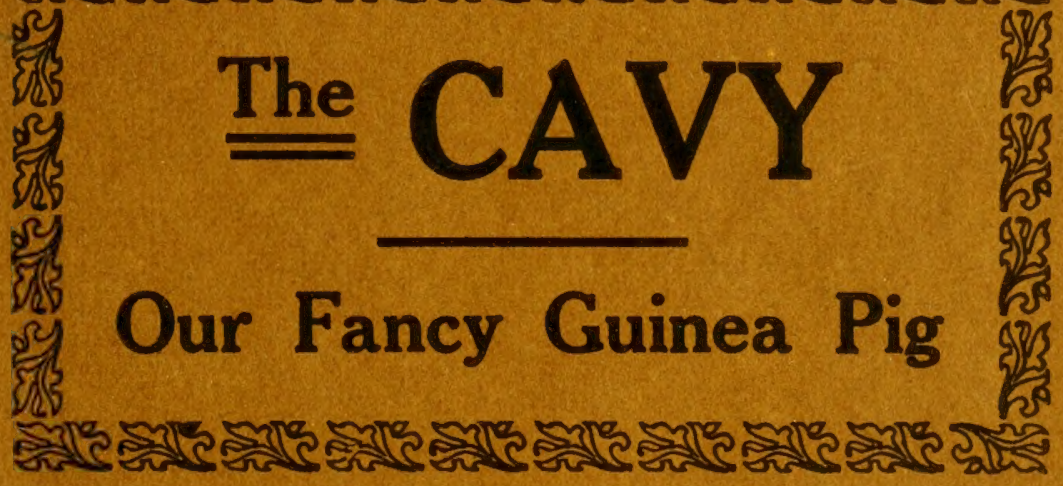





\title{
THE CAVY
}

\section{OUR FANCY GUINEA PIG}

\author{
Written by \\ J. HENRI WAGNER, \\ "President American Fur Fanciers Association of America." \\ Washington, D. C.
}

Published by

PET STOCK IVORLD COMPANY,

Baltimore, Md.

Copyright, by August M. Roth, 1915. 


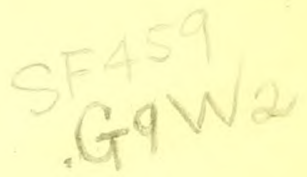

(C) Cl.A410668 


\section{Introduction.}

In offering to the pet stock world this booklet on "The Cavy, Our Fancy Guinea Pig," I do not wish it to be considered as covering every phase of the cavy fancy. This would be an impossibility. It is, however, different from anything heretofore published. Some of the books now on the market lack many of the essentials which go to educate the novice along the lines so necessary in the production of a successful exhibition cavy; while others contain a profusion of irrelevancy which the present day business man has no time to read. I have endeavored to present, with such simplicity that a child may readily understand, the most important cares in connection with the rearing of this interesting pet, and I trust the information contained herein may be of as much benefit to the young fancier as it has been my pleasure to impart.

J. HENRI WAGNER. 



\section{THE CAVY}

\section{OUR FANCY GUINEA PIG}

\section{Habitat-Description.}

The cavy, or guinea pig, as it is commonly known, is the name applied to several Sonth American rodent animals included in the "cavidae" family, but naturalists apply it, perhaps more properly, to the genus "cavia."

The cavy, in its wild state, is distributed over an extensive area of South America and is represented by several species: the more common being the aperea or cobaya (restless cavy) of Brazil; the Bolivian cavy, boliviensis, found at great elevations in the Andes Mountains; the Brazilian rock-cavy, cavia rupestris, characterized by its short blunt claws, and the Peruvian cavia cutleri, which is supposed to have been tamed by the Incas, the reigning aristocratic and priestly caste of Ancient Peru, between 1240 and 1523. This theory seems quite plausible when we consider the marvelous development of the Llama which is accredited to the Incas, who regarded this animal as royal property, and almost as sacred as to India its white elephant.

The early history of the cavy is so veiled in mystery that it is questionable whether our common guinea pig descended from the specie known as cavia porcellus or cavia aperea of Brazil, the cavia cobaya, or the Peruvian cavia cutleri. Its introduction into Europe after the conquest of 


\section{2 THE CAVY.-OUR FANCY GUINEA PIG.}

Peru by the Spaniards warrants the conclusion that it must have been the pet of the remarkable peoples that inhabited the fabled gold-laden country of the Andes.

The name "guinea pig" appears to be a misnomer of unknown origin, some authorities conjecturing that it is a corruption of guinea-pig; others, that it was derived from the association with the English coin, "guinea," for which it is said to have been sold in England during the sixteenth and seventeenth centuries; and still others that the word "guinea" merely signifies foreign.

The cavy is a small quadruped, rarely weighing over three pounds, its normal weight being about two and a half pounds. It is stontly, well built, with short, rounded ears: the tail, while conspicuous by its absence, is rudimentary. It has four front and three hind toes, imperfect collar bones, the incisor teeth short and the outer surface of the lower jaw marked by a distinct ridge.

Being a herbivorous animal, it feeds upon nearly all vegetable substances, and while its requirements for water are small it seems to thrive better with a supply at hand at all times. Its never failing appetite prompts it to be always on the alert for its master and it manifests its pleasure in seeing him, as well as to indicate that it is awaiting another portion of food, by a succession of faint squeaks and grunts.

In its wild state the cavy, while a fertile breeder, produces but one or two young at birth, and then only once a year. The domesticated pig produces from two to five litters a year, with as many as seven in a single litter. The young are fully developed when born, eyes open, bodies covered with fur and of the same color as when full grown. While the young are not weaned until the third week, they commence eating after the first day of their existence. 
The cavy is a singularly inoffensive and defenceless creature, of a very excitable disposition, and lacks that intelligence which usually characterizes domestic pets, although some have been trained by animal trainers for the stage. It is said to be used in the country of its nativity as food for human consumption, but the demand for cavy flesh has never spread to the northern continent, nor to Europe. No use has yet been put to its fur, which, unlike most fur animals, it is constantly shedding. The cavy is, however, used extensively for the propagation and testing of antitoxins and for other experimentations in laboratories. Beyond this, it is of no particular service to man and the statement that it may be used to drive off rats and mice is without foundation. As a pet for children, however, it is une of the best obtainable, being perfectly harmless.

Because of its great fecundity and the ease with which it vields to experiment the fancier has taken a keen interest in this little creature and since the middle of the nineteenth century wonderful strides have been made in perfecting it to the standard which man thinks Nature should have adopted in its natural law of selection. From the vari-colored wild animal the patient fancier, aided by "Father Time" has produced a dozen distinct colors and combinations of the rarest hues, as well as the most freakish abnormalities, from Nature's standpoint, in its shape and length of coat. It has risen from its insignificance and humble wandering life among acquatic plants in marshy districts, and the crags in the mountain sides of South America, to the distinction of being groomed and petted by the aristocracy of the British Empire and other leaders of society throughout the civilized world. 


\section{Housing.}

The subject of housing is one that requires considerable study if the fancier contemplates extensive breeding. Time is a great factor in every business. If the fancier is satisfied with a few cavies, two or three shoe cases or soap boxes will answer the purpose. If, on the other hand, he has higher aspirations, he should build and arrange his hutches so as to minimize the amount of labor required in cleaning. Ideal hutches may be cheaply constructed of ordinary flooring, tongued and grooved; covered with halfinch wire mesh to keep out rats and mice, which not only eat the food, but devour the young.

In building the hutches here shown, which can also be used for rabbits, the floors are made removable to facilitate cleaning. They slope toward the rear of the hutches-the slope being one inch in two feet (the outside width of the hutches). The floors themselves, however, are but twenty inches in depth, as the entire rear part of the hutches is equipped with a four-inch galvanized iron gutter, such as is used under the eaves of houses, which is covered with half-inch wire mesh. Cavies invariably seek the darkest part of the hutch to secrete their offal, and the above hutches are so constructed that the urine and droppings are precipitated through the wire mesh into the gutter, thereby keeping the floors dry at all times and preventing the cavies from lying on damp litter and avoiding consequent colds and other diseases. In cleaning the hutches all that is necessary is to scrape stray droppings into the gutter, remove the floor and gutter, which rest on the side strips supporting the floor, clean, and return to their respective places. It requires but thirty or forty minutes 
THE CAVY.-CUR FANCY GUINEA PIG.

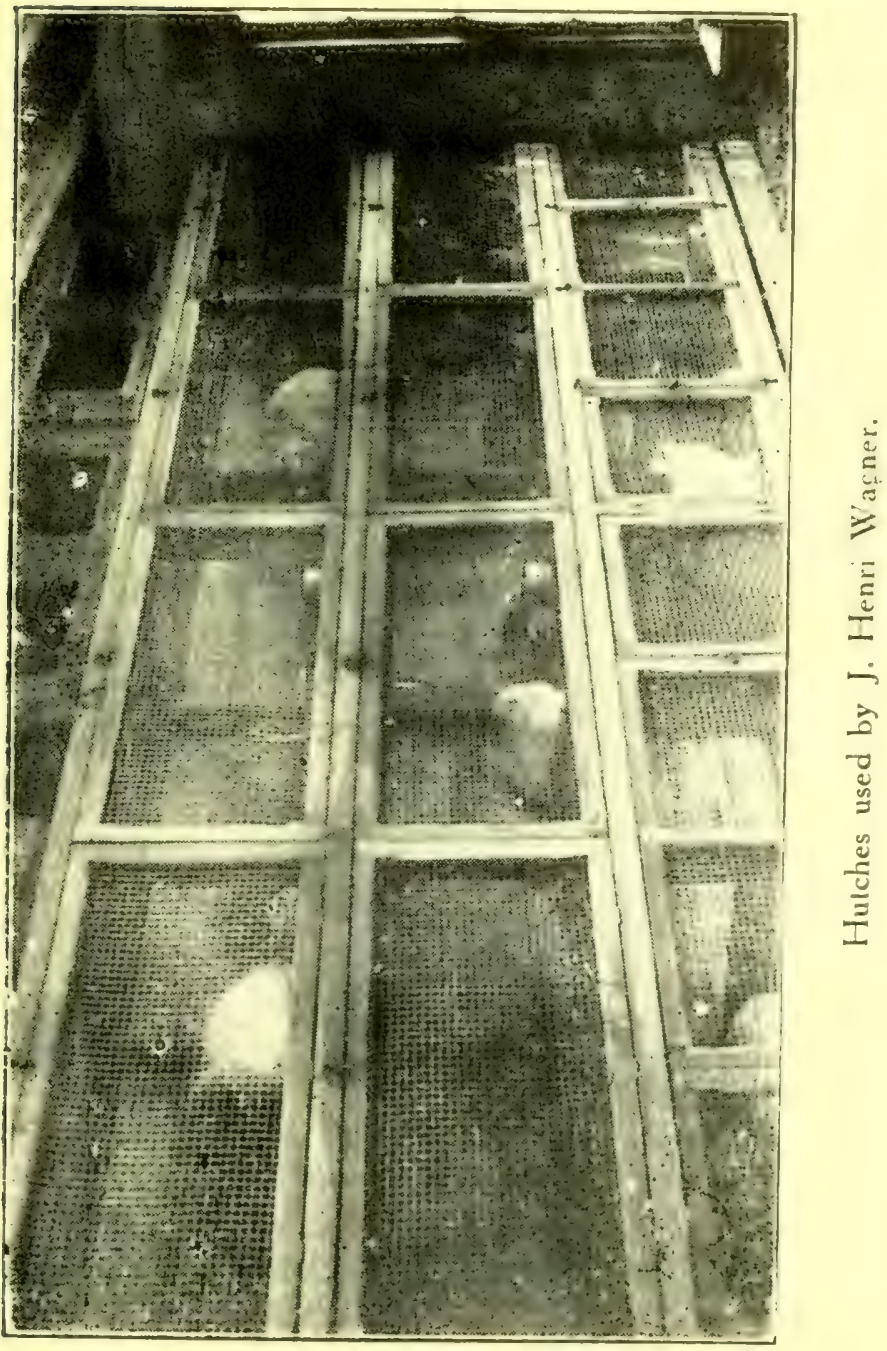


to clean a dozen hutches constructed along these lines.

The old adage: "cleanliness is next to Godliness," is just as applicable to the successful raising of cavies as to longevity of life in the human race, for most of the fatal diseases contracted by cavies are due to filth or impure food and water.

Hutches should be roomy, yet free from draughts. Plenty of exercise not only aids digestion, but creates a bigger appetite. which encourages growth. If the hutches are constructed of the size illustrated, to wit: three feet long, two feet deep and eighteen inches high, each one will accommodate one boar and three sows without crowding. and at the same time give the "restless cavy" an opportunity to keep moving most of the time, as cavies are more active when a few are kept together than when they are alone. They should be so placed as to receive the rays of the sun, for there is no better germicide than sunlight.

A cavy can be bred at the age of two months. but early breeding stunts the growth of the sow and renders it unsuitable for exhibition purposes. Early breeding also results in the production of undersized youngsters. Size is a great factor, when the judge's eye falls upon his subject. Sows should not be bred before they are seven or eight months old. It is not wise to permit more than three sows to run with one boar, although many fanciers advocate as many as five. The young are usually weaned the third week, at the end of which time the sexes should be separated and each sex placed in a separate run for development. Males may be allowed to run together, as a rule, until four or five months of age, without seriously molesting each other, but in so doing, the fancier runs the risk of having a few slit ears, which disqualifies a cavy in competition. It is well to give the sow a few weeks rest, after pigging, to regain her normal strength before breeding her again. This is particularly necessary where sows are permitted to raise large litters. A cavy has but two teats, and the drain on her vitality is great when compelled to rear a large family. 
THE CAVY.-CUR FANCY GUINEA P.G.

Bieeding.

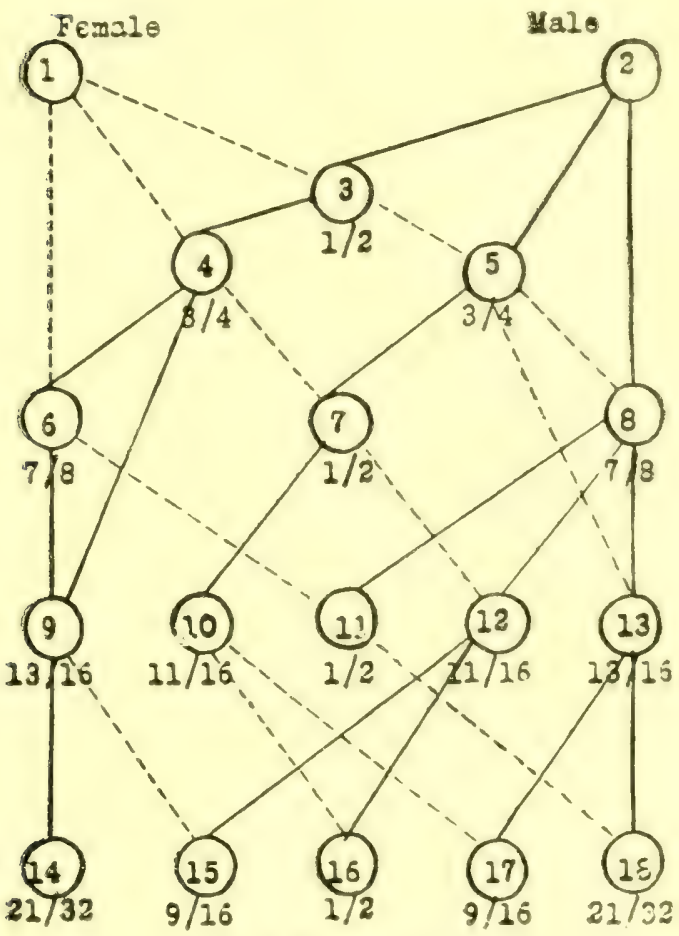

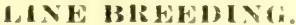

A good strain can best he perpetuated and imm wod hy an iniclli. syent system of line lreeding. Study the chart. lie sure and begin with strong, vigorous prgs, those that have not heen too closely bred.

Regin at the to\%. Note that the male is always rejrescired by a solid line, the female liy a dotted line.

fach circle represents the progeny, viz.:

No. 1 materl to No. 2 produces group No. 3, which is one-half the blood of sire and dam.

A male from group) No. 3 mated black to his own dam (Xo. I) groduce gromp $\mathrm{N}_{0}$. 4 , which is three-cuarters the blood of the dam (No. 1) and one-quarter the blood of the sire (No. 2).

The fractions illustrate relationship letween new gromps and the original pigs.

Follow this nlan on down and we have in No. 16 the new strain. and in No. 18 the strain of our original sire No. 2, thus giving us 3 ristinct strains, and by this sysicin we may go on lireeding indelinitely. 
In order to attain the best results. line breeding must be indulged in, and occasional inbreeding will do no harm. but care must be exercised not to inbreed to excess. Study the line breeding chart here illustrated. It will pay you. This may be overcome by introducing a new unrelated boar into the caviary when the stock appears to lose its vitality and quality. In purchasing a new stud boar explicit instructions relative to the prominent points desired should be given to the fancier from whom it is being ordered, or years of effort may be wasted.

Remember that strength of bone, color of eyes, markings, color and length of coat, are usually transmitted through the boar, while constitution, shape of body, or type, size, and quality of coat, through the sow. Of course this rule is open to exceptions, like all others when there is interference with the law of natural selection. It is not unusual for cavies sometimes to produce young with characteristics that do not appear in either parent, but which existed in some distant ancestor, and which lay dormant until the propitious moment for its reappearance. It is therefore unwise to mate two cavies, possessing the same aults-such as too light or too dark a coat, pointed faces. or badly shaped ears, etc. As stated by our English fancier-author, Mr. C. A. House, "In mating we want not only to pair two animals together, but they want to be so mated that the good and bad points of each will blend into oneif not perfect-almost perfect whole. We weigh up careinlly all the little differences in shape, size, coat, color, etc. and then pair the pets so as to get as many good points. and as few had ones as possible."

There are many reasons why this rule will not produce inst what the fancier anticipates and desires, such as var1- 
ance in the ages of the breeders, inferior quality in some of the points in an ancestor of one of the mates, or the prepotency of one or the other. Many a winner is produced by mating an old sow possessed of good color, coat and shape with one of her sons which carries the good qualities of the father. and the old boar with his daughter: while even better results are sometimes attained by crossing brother and sister. The continuance of such a practice for a prolonged period is, however, to be discouramed.

Only the best specimens should be used for breeding purposes. They should likewise be in the best condition before mating. It is well to kill all culls-mismarked, illshaped and deformed-at birth, so that the strength of the mother may be used entirely to develop the best offspring.

Finally, purchase new stock only from reliable fanciers who have developed their strains by persistent line breeding: who will guarantee strong, healthy breeders, and who can produce the show catalogs to confirm their assertion that their stock won in competition with other fanciers. and not with their own stock. Such stock will be of henefit in building up a strain, and no other. 


\section{Feeding.}

The subjest of feeding is one which is usually governed by the experience and whim of each individual fancier. Aside from advising that only pure. clean food be syscomatically supplied to the cavies during the various stages of their lives and condition. little can be said.

The cavy is not particular about the variety of food offered, but it insists that whatever it be it must be clean. In the way of solid foods: hay, oats, cracked corn, wheat. bread occasionally, and the many varieties of meals, may be fed: while in greens, they are very fond of water cress. clover and other grasses. lettuce, dandelion, chickery, plantain, parsley, carrots, bects, and, in fact, almost any greens. some fanciers discourage feeding raw potatoes and cabhage, as they have a tendency to cause diarrhoea.

It will be found to be most economical, as well as productive of the hest results, if only wholesome food be offered tr) cavies. 'l'his is particularly so in "forcing" the growth of young pigs. Regularity in the hours of feeding. as well as the quantity fed, also require careful observance. The cry needs to be fed only twice a day, although some fanuics wive an extra treat at noon time. A good schedule is to feed a bountiful supply of hay and some oats and other grains. as well as a small handful of greens or roots for each pro, between six and eight oclock in the morning. lietween four and six oclock in the evening. fresh water and some more hay and grain will carry them through the night. In summer time they should have water twice a day. In the winter months the water should be iust warm enomgh to take off the chill, while in summer they deligint 
in drinking cool water. The pigs do not need a second invitation to partake of water in winter or summer when offered in this manner. I have experimented along the lines suggested by some fanciers-i. e., not giving any water except on extremely warm days, and my experience has been that the cavies which have had water before them at all times are in much better condition and give better results than those which do not receive any water at all or at rare intervals.

Particular attention should be paid to sows in litter, because toward the close of the gestatory period and while suckling their young they require more grasses, greens and roots than at other times. At these periods carrots and sprouted oats may be fed more liberally as they increase the supply of milk. Milk may also be offered at this time as both sows and young will welcome it and it will be found to give good results.

English fanciers recommend a number of mashes and mixtures, but I have never found them necessary under the system of feeding I have adopted. Of course. I doubt not that the mashes are very nourishing and beneficial. but considering the time and labor, I have not been able to reconcile myself to the belief that they are necessary.

Remember that foul water, mouldy hay and oats, and frosted roots or overheated grasses will cause more diseases and deaths than anything else. 


\section{Diseases.}

Sunlight is a sermicide and that foul water and feed are the causes of many diseases.

Diarthoea is the caluse of more deaths in the cariary than any other disease, and is mostly due to improper feeding. Unless prompt measures are taken inmuediately after the disease is discovered, drugs are of little avail. Some fanciers recommend from lifteen to twenty drops of castor oil or sweet oil: followed shortly afterward with three or four drops of lavinum. While this treatment is being administered $i t$ is isest to remove all food from the hutch for twenty-four hours, and thereafter begin feeding with a little hay and oats and fresh water. Do not feed greens for several days after the disease is checked. Sudden changes from food with a low percentage of protein and fats to food containing a high percentage often cause diarrhoea, such as changing from timothy to alfalfa hay; oats to soaked Canada or maple peas, ete.

Co'ds manifest themselves in several was: A dry congh; affections of the eyes. a watery-like substanca : anning therefrom: and pnenmonia. These are most generally caused by draughts or subjecting the caries to sudden changes of temperature. For the last named, there is little hope of effecting a cure, hut for ordinary colds two drops of aconite in a teaspoonful of water or milk will often relieve the trouble. For the eyes a solution of boracic acid composed of a teaspoonful to half a tumbler of water is effective.

Bare Patches are often caused by lice nibbling at the 
coat, or they ma be caused by over-heated blood. A pinch of powdered sulphur in their food and plenty of green food will obviate the trouble if caused by the latter. A paste composed of a little sulphur and sweet oil should be rubbed into the bare patches daily for several days. However, if lice are found to be the cause, after applying the sulphur and sweet oil paste, dust well with a lice powder or wash with a weak solution of carbolic acid and water. say half teaspoonful to two quarts.

These diseases are the most common and such as require prompt measures. There are other diseases such as tuberculosis (going light), paralysis, etc., which are rarely cured, and unless it is a very valuable animal time and trouble may be saved by destroying it. 


\section{Varieties and Standards.}

This subject has been sadly neglected by our authors. and is one that should, next to feeding, stand foremost in our mind's eye. Too many of us forget the IDEAL, or the standard of perfection which we should follow as ou: guide, and instead dote on some particular shade of color. shape or setting of ears, or "buffalo" shoulders, and forget the average of all the points for which we should strive.

\section{English.}

The structure of the English cavy is described by Mr. House as follows: "The English cavy must be cobby. Its head large and chubby, with a good Roman nose; the eyes should be bold, bright, and prominent, the neck short. with great depth of shoulder, the back broad and massive, with well-formed hindquarters; the ears should be well set on, and droop gracefully, not enough to be styled umbrellas, but just a nice, well-turned droop. Prick ears give a rat-like appearance to the head. The coat should in all varieties be short, perfectly smooth, and very soft and silky to the touch."

In this variety we have, at present, six self, or solid colors: black, red, cream, white, chocolate, and blue. The last two colors are still in their infancy, although considerable progress has been made in perfecting the same.

In the broken, or vari-colored, are the tortoise shell (black and red), tortoise shell and white (black, red and white), Dutch, Colden Agouti, Silver Agouti, Himalayan, and Brindle. A steady advance is also being made in producing such combinations as agouti, red and white; chocolate, red and white; and cinnamon colored. These, when 
THE CAVY.-OUR FANCY GUINEA PIG.

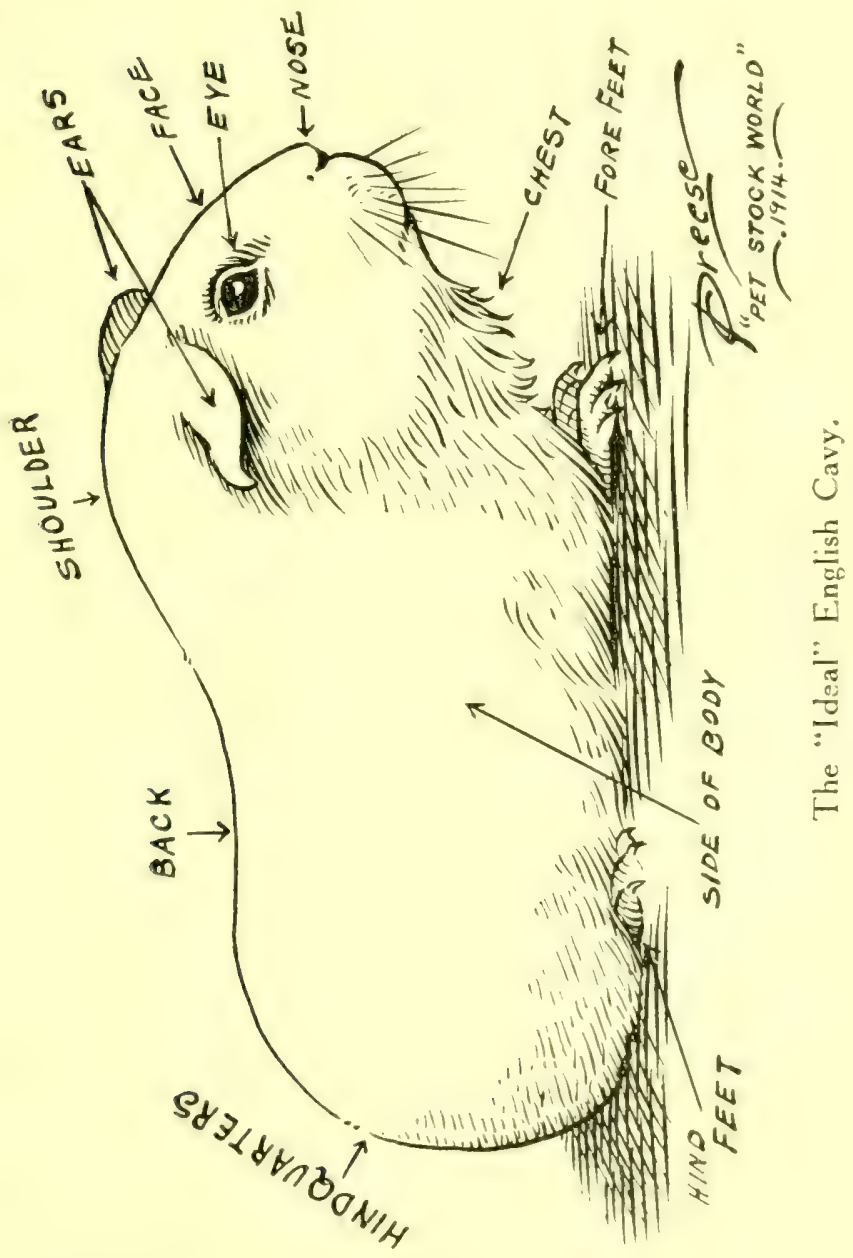

In the illustration we have the typical linglish Cavy, so ahly drawn by 1)reese, the artist, for Pet Stock Wrorld. 
eventually perfected, will create quite an interest as they are most dificult to produce.

The BLACK cary should be of the intense blackness of the Raven, full of lustre, with a line, sleek coat. It is an easy matter to obtain a good outer coat, but the deep black color should extend to the shin. It is frequently necessary to introduce white or red into the black cavy, which must always be through the sow. 'This will enrich the color, while an agouti cross will be found to improve the silkiness of the coat.

The RED caly is described hy some as a "rich, bright orange," and by others as a "tomato red." The greatest care should he cxercised to keep out the mahogany color. Some fanciers introduce a cream sow to the red stud boar when the red lecomes too dark and pronounced.

Like the hlack, it soll at times to cross a red hoar with a tortoise and white sow to enrich the color, and with a colden agouti sow to improve the quality of the coat.

The CRFi.1I should be just as its name indicates. The Inglishman calls it "Devonshire" cream. It should not be too dirts, as many of the creams are too near an orange color, rather than cream. However, when cream comes too light, it may be well to introduce darker color by the use of a red sow.

The WHI'TE, should be snowy white, with white ears and pink eyes. being albinos they almost invariably breed true to color, and when so bred they usually have very pretty ears. But when crossed with a dark colored pig, the ears will have a dirty appearance. This should be aroided. 
The CHOCOLATI cary should be the color of a fresh cake of chocolate; miformly colored over entire body. including ears, feet and toc nails. The color should extend down the full length of the hair, right to the skin.

The BLUE is not only the latest color prodmed in the self varieties, but the least perfected as well. The shades thus far presented are too slaty, and appear to be no more than faded black. When finally perfected this will be one of the most beautiful colors obtainable in caries.

The TORTOISE SHELL is a rarity in the United States. and in fact $T$ learn that it is not as popular in England as the TORTOISE SHELL AND WHITE. In the forme. the colors should be red and black: while in the latter white is added. There should be absolutely no brindling of colors, that is to say intermixing, and the patches should be as numerous and uniform as possible. The tortoiseshell and white may have a one. two or three colored face. the latter, when olstained with a good white blaze, being the most attractive.

The DUTCII and HIMALAYAX shonld be marked similar to the rabbits of the same colors. The former has been bred for a longer period than the latter, hence has reached a higher state of perfection. Both are exceedingly difficult to produce, if one aims at perfection; and when the specimens are anywhere near the "ideal," they are beatiful to behold. The "Ideal Dutch Cary" illustrated herein gives an excellent idea as to the beatuty of this little creature if it could be perfectly produced. In the Himalayan, all ends should be of some solid color other than white. while the rest of the body should be snowy white. free from brindling. 


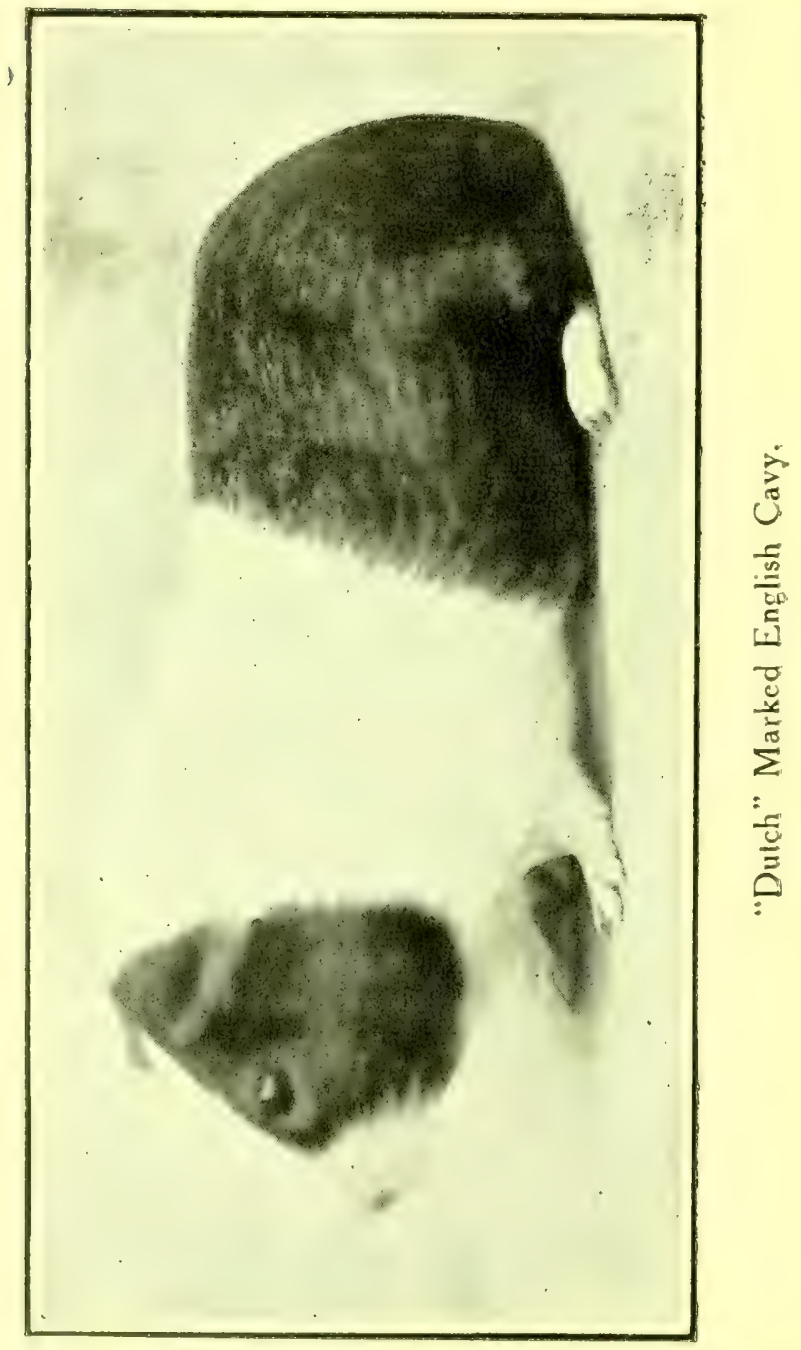


THE CAVY,-OUR FANCY GUINEA PIG.

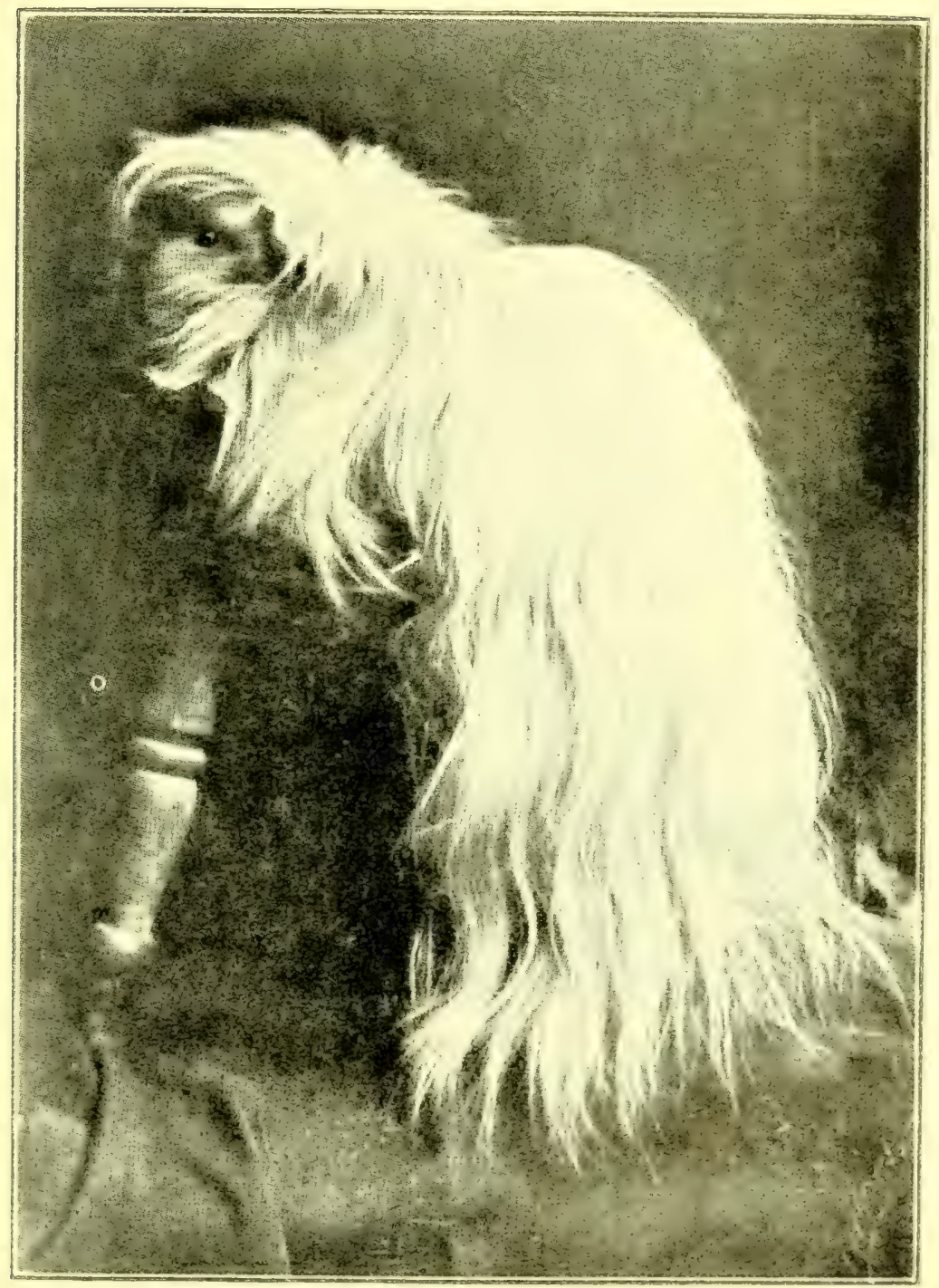

"Peruvian" Cavy. Courlesy Doubleday, Page \& Co. and J. Henri Wagner. 
AGOU'TI is the name applied to the variety whose color has been copied from the wild Agouti, or "Cotia" in Portuguese, native of Brazil. The wild agouti and cavy are not related, only the color of the former having attracted the inventive and imitative eye of the fancier. This variety made its first appearance in the Crystal Palace Show, London, in 1888. It is bred in two combinations. golden and grey, or silver. The formes should be of a rich golden brown, while the latter a silvery grey, both evenly ticked on top, sides, chest and feet, but void of ticking on belly. In the golden agouti the belly should be rich, deep red; while in the silver agouti a pearl grey color should be attained.

The BRINDLE cavy is not popular, because it is not as beautiful as any of the self or broken colored varieties, and is probably the most difficult to breed. The brindling is not easily obtained and even the most ardent and patient fancier becomes discouraged before he has half reached the goal.

\section{Peruvian.}

The Peruvian Cavy, as a variety, stands in a class by itself. While it doubtless originated in the same country as the English Cavy, it is the common belief that its outward characteristics were developed in France, and later improved by the English pioneer fanciers. Length of coat, head furnishing, and texture or silkiness of coat, are the principal points for which the Peruvian admirer strives. The importance of these three characteristics may be appreciated when we consider that fifty-five points out of a possible hundred are allotted to them in the standard. The 
Peruvian is larger than the English or the Abysinian: while the head alone is proportionately not so large as in the other varieties. The colors produced in this varicty are the same as in the other two.

The Peruvian cannot withstand much dampness, because its coat appears to absorb moisture which endangers its health and consequent exhibition quality. It shomld be bred indoors under a normal, dry temperature. Neither sawdust nor hay should be used for bedding, as both woik into the hair and cause it to become tangled. Straw. cut in six-inch lengths, makes a good bedding material. When the hair reaches the length of, say, eight inches, it should be put up in "crimpers" such as the women use in their hair, or plaited, to prevent spoiling the coat. The hair may be taken down once a week, brushed well, and put up again.

While breeding. the coats should be clipped as the lons hair not only annoys the breeders and bec, nes matted. but interferes with the various duties they have to perform.

Many fanciers of the patient and painstaking type use hair tonics and restorers to increase the lineness and silliiness of coat, and also feed especially for length of the coat; boiled rice and rice puddings being used in the latter instance.

\section{Abyssinian.}

The Abysinian, like the Pertwian, did not derive its name by any geographical association and undoubtedly emanated from the same source as all other caries. It has been steadily improved both in harshness of coat and the number of rosettes, which are its principal chararteristics. The more numerous the rosettes the better; as many as fifteen, and rarely more, having been produced 
22 THE CAVY,-OUR FANCY GUINEA PIG.

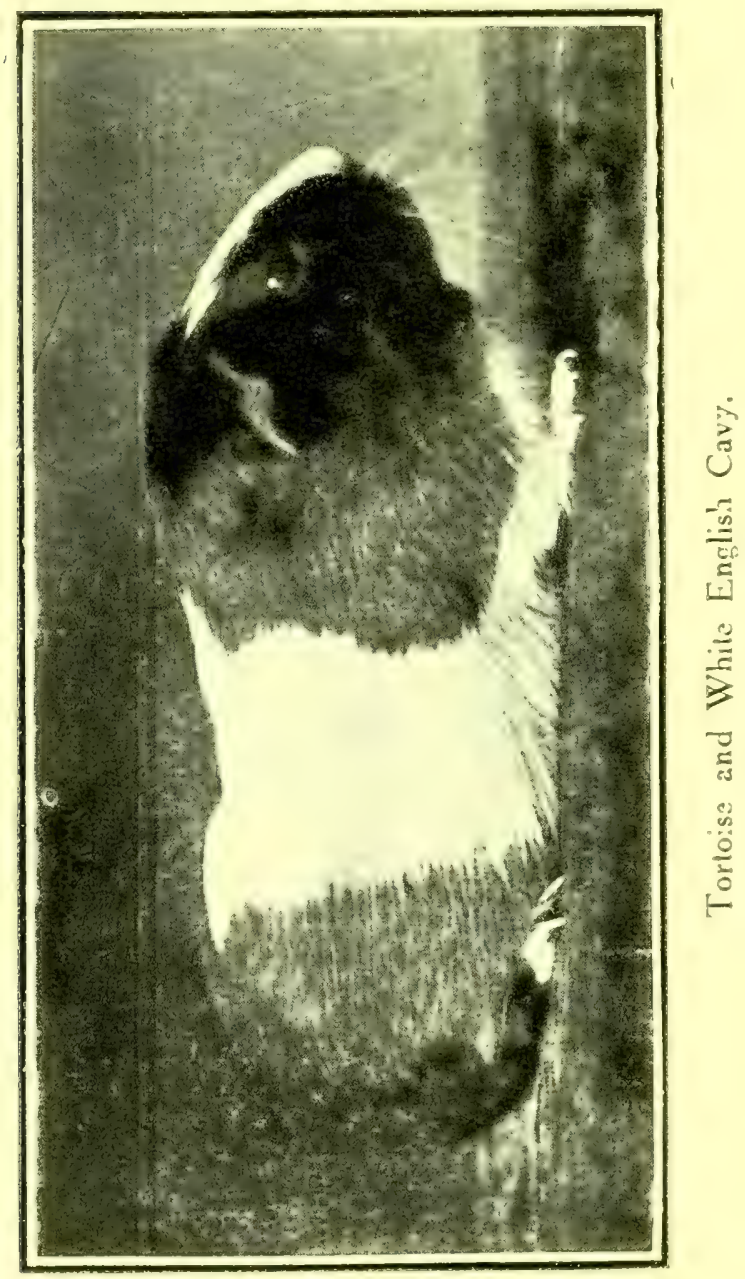


on a single cavy. The hair of the Abyssinian should be brushed toward the head, and each rosette carefully shaped up with a tooth-brush. The least attention to the coat of this variety will demonstrate the best results, as constant grooming will impair the harshness of the coat. It is well to maintain outdoor hutches for this variety, provided they are free from damp and draught, as the cold is conrucive to the production of harshness in the coat.

The Abyssinian yields to color-breeding with equal readiness as the English and Peruvian, and the same rules for improving the quality of the coat and color apply to this variety as have been explained for the other two. Sixty points out of a hundred are devoted to rocettes, cont. and head furnishing, while only 20 points are allowed for size and shape. The attention to coat should, therefore, be paramount. As the quality of the coat is usually obtained through the sow, it is preferable to use only harsh-coated sows as breeders: while the boar should be well covered with rosettes, possessed of good color and size. The "weeding out" process may be begun at the birth of the youngsters, as it is easy to determine when the young are but a few days old which are best in rosettes and color, and the weaklings and mismarked caries killed.

In feeding Abyssinians rice puddings, milk, and meal mashes should be a rarity and only given as conditioners; the principal diet consisting of hay, corn, and a few oats and greens. 


\section{Exhibiting.}

Exhibiting is the result of the efforts of the fancier in following the advice of his older brethren; the rules laid down for the housing, breeding, and feeding of his stock: and his own practical experience. It is the zenith of his ambitions and the telltale of his success or failure. Temporary misfortune on the show bench should not dis-

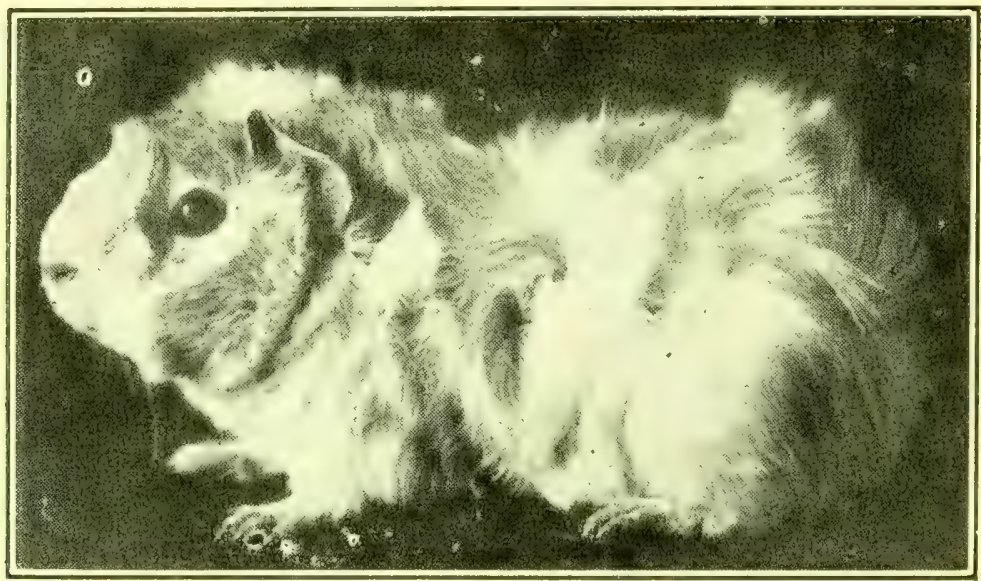

Cream Abyssinian Cavy. Couriesy T. A. Marin, Jr.,

courage the novice, for it may be merely his inahility to judge his own stock, in making his various matings, or lack of experience in any one of the several departments of carydom that causes him to be beaten. Success is bound to come to the observing breeder, coupled with common sense methods. The ambitious fancier will visit the show: and acquaint limself, by kindly inquiry of the judges and 
THE CAVY.-OUR FANCY GUINEA PIG.

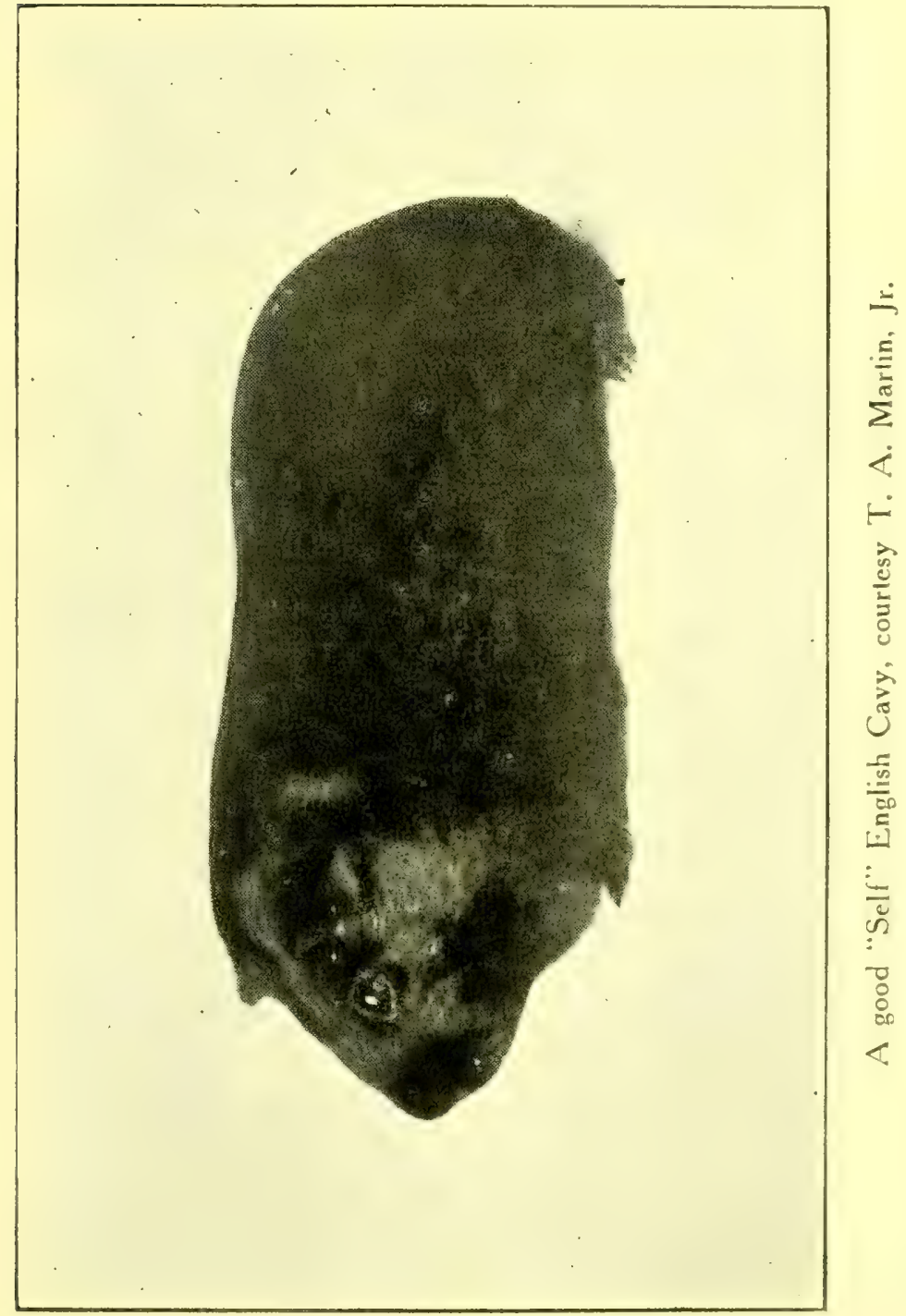


well informed veterans, wherein his shortcomings are manifest. He will return to his little family of quadrupeds and apply the knowledge thus conveyed to him. and when the next season returns, to his utter amazement, the laurels find their way to this patient, persevering lover of industry.

His success should not tempt him to over-exhibit or to greedily seek to "corner" all the prizes on his severa! varieties, for after a few shows his stock will succumb tc. the strain of travel, rough handling, close and foul continement, unsystematic feeding, and his season is closed. On the other hand, he should plan his exhibits so that sufficient time elapses between events to allow the show specimens to recuperate so that when their turn again arrives they may be able to meet the jealous pride of some fellow animal.

The cautious fancier will provide himself with a good conditioning mixture, and feed only the most appetizing foods at these times, both before and after each show. The brush and silk or chamois skin will here demonstrate its usefulness, for the critical eye of the judge manifests his true sport by showing his preference for the well-groomed specimen. Many fanciers even supplement the brush and silk with a good rub with a whisp of hay and later with the hand, which brings the gloss to the surface. In fact there are some who feed small quantities of flax seed meal which renders the hair oily and facilitates the production of the shiny coat.

In the case of white cavies, washing a few days before a show might not be amiss.

When shipping cavies to distant cities for exhibition purposes, do not use any old store box that may be available. Such boxes are not only irritating to the show at- 
tendants and may subject the cavies to careless treatment as a consequence, but are subject to improper handling by railroad employes. A little time and judgment may be well spent in making a case out of light wood, with a compartment for each specimen, good ventilation, and carrying handles. Each compartment should have a bountiful supply of hay before shipping, and in addition a carrot or two, and a piece of stale bread. Also see that the exhibits are shipped in good time so that all time and trouble in their rearing and preparation may not be wasted by their late arrival and consequent elimination from competition. 


\section{Conclusion.}

I have not mentioned the various standiards which are provided by the fancy because they are subject to change, and because the true fancier will keep in constant touch with them by joining one or more of the pet stock associations. At the present time we have, in this country. three general associations: The American Fur Fanciers Association, the National Pet Stock Association, and the Pacific Pet Stock Association.

The Englishman is accredited with the distinction of elevating the cavy from its wild state to the show bench. and certainly has he, as a pioneer, surpassed all other nationalities in providing, in the development of this littl. creature, a lucrative pastime for the weary and fatigued business, professional and workingman, and by persistent and painstaking effort maintained his supremacy in the perfection of exhibition stock. That most of the interest manifested in the fancy in England is due to the activities of Fur and Feather, published in Idle, Bradford, is unques. tioned, for without a leader nothing can withstand the frailty of human resolutions. Its able editor. Mr. C. A. House, was not only one of the pioneer cavy fanciers, bit has made the pet stock fancy his life work; having been a constant admire of pets during the thirty years which have elapsed since his first exhibit with the National Cavy Club of England, at Pulborough in 1888.

Americ is fast coming to the front, however, and ere long it is hoped that our own results will be felt in the greatest of all shows-The Crystal Palace. Distance and fatigung travel have been the oreat barriers. but the ravirl itrides which have been made during recent years in navi- 
gation on sea and in air warrant the prediction that soon American fanciers will experience less risk in competing with our English brethren. This goal is the height of the American fanciers' ambition, and when it will have been reached there need he mo anxiety that America cannos hold its supremacy in the pet stock world as it has in many other sports which it has wrung from the old world. 


\section{J. Henri Wagner}

\section{Importer and Breeder of}

\section{FANCY RABBITS}

Eight years of practical experiment with pigeons, rabbits and cavies in Mendel's theories on the laws of heredity have equipped me for properly breeding pet stock for type, yuality of hair, station and those other elements which constitute the real exhibition and utility animal. My foundation stock was imported from England's best strains, which, by proper line breeding has produced a strain of wonderful winning quality.

\section{English, Angora, Belgian and Dutch}

\section{a Specialty}

Usually a few youngsters on hand for sale at prices consistent with careful breeding. REMEMBER, I kill all culls at birth, using the strength of the mother only to rear healthy and vigorous animals.

\section{N. Capitol St. WASHINGTON, D. C.}




\section{THE ENGLISH JOURNAL}

FOR LOVERS OF

\section{RABBITS, CATS AND CAVIES}

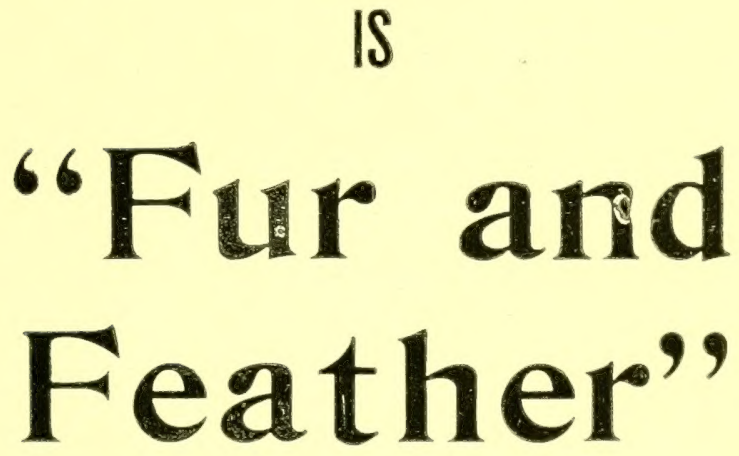

On its staff are all the best and most experienced breeders and judges in England.

It gives the most instructive articles, the brightest and most up-to-date news, and the most reliable advice.

$$
\begin{gathered}
\text { Yearly Subscription, } \\
\text { U.S. A., } \$ 2.50
\end{gathered}
$$

OFFICES; IDLE, BRADF0RD, ENGLAND 


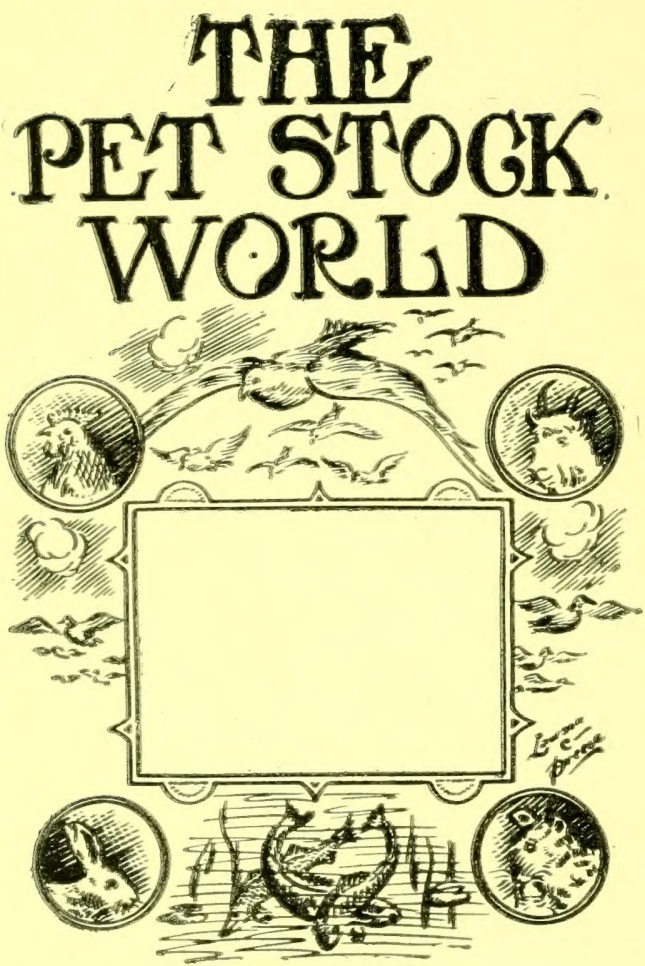

Devoted to the Rabbit, Cavy, Ban$t=m$, Mouse, Rat, Cat, Pigeon, Gold and Tropical Fish, etc.

Prints more Pet Stock News than any other publication in America.

Single copies, 10c. Yearly, 50c.

Order of any Pet Stock Dealer or Newsdealer or from us.

PET STOCK WORLD CO., Baltimore, - - - M. 
